\title{
Stage 0 Esophageal Cancer AJCC v6
}

National Cancer Institute

\section{Source}

National Cancer Institute. Stage O Esophageal Cancer A/CC v6. NCI Thesaurus. Code C3637.

Stage 0 includes: T is, N0, MO. T is: Carcinoma in situ. N0: No regional lymph node metastasis. M0: No distant metastasis. (AJCC 6th ed.) - 2003 